\title{
Application of grout slurries with the Defecate addition for effective well cementing
}

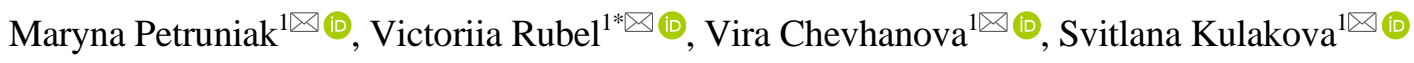

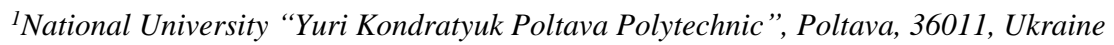 \\ *Corresponding author: e-mail veca.rubel@gmail.com, tel. +380502226319
}

\begin{abstract}
Purpose. Research and substantiating the expediency of cement mix formulations of grout slurries with different Defecate additive content and their effective use when cementing the reservoirs prone to absorption of the cement slurry, as well as to prevent behind-the-casing flows and for cementing operations in the zone of abnormal pressures (hydraulic seam fracturing).

Methods. Analytical and experimental studies of the physical-chemical grout slurry properties are used: determining the influence of the Defecate additive content on the cement mixture technological properties; study of a change in the grout slurry rheological characteristics at various temperature conditions; testing the formulation of grout slurry with different rates of strength development; substantiating the economic efficiency of using the grout mixtures with the Defecate additive.

Findings. It has been revealed that the cement mixture fluidity increases by $10-20 \%$ with the addition of a Defecate in the proportion of 5-20\%. With a further increase in the Defecate content, the stone strength deteriorates, and with a decrease, the grout slurry concentration increases. It has been found that when Defecate is added to the cement mixture in a proportion of $20 \%$, the pumpability of the cement slurry doubles, that is, from 1.5 to 3 hours. The economic efficiency has been proved of using these mixtures during insulating activities in the well No. 122 of the Kulychykhynske NHKR (oil and gas condensate field). The improved formulations of grout slurry with the addition of a Defecate are recommended to be used during repairinsulation works for delimitation of producing reservoirs prone to absorption, behind-the-casing flows and hydraulic fracturing.

Originality. New dependences have been determined of the technological and rheological characteristics of grout slurries on the content of the Defecate additive, which makes it possible to set its optimal proportion.

Practical implications. The use of grout mixture based on the Defecate will expand the raw material base for obtaining lightweight grout slurries. The properties of such a solution make it possible to use a grout mixture for cementing wells in the zone of abnormal pressures, while reducing the costs for the process of reservoir delimitation.
\end{abstract}

Keywords: well, behind-the-casing flows, producing reservoir, grout slurry, Defecate

\section{Introduction}

Currently, both in Ukraine and in other countries, from 10 to $60 \%$ of wells require capital repairs or even abandonment due to emerging behind-the-casing flows [1]-[3]. This is caused by an emergence of behind-the-casing flows, which lead to premature flooding of wells, which do not confirm the initial hydrocarbon reserves, and also pose a threat to the environment and human safety. The problem is very relevant for oil and gas companies both in Ukraine and in the world [4][5].

It is well known that flooding of wells during operation makes them unsuitable for efficient operation, causing irreparable losses of oil and gas, contamination of subsoil, deterioration of the ecological situation, creating a fire hazard. This leads to an increase in the stock of inactive wells, which require very high costs to be restored [6].
Analysis of operational information from NGDU Poltavanaftogaz, PJSC Ukrnafta and PoltavaGasVydobuvannya GPD for 2006-2019 has shown that during the wells operation by these enterprises, a significant number of them have intercasing pressure, and there is a tendency to an increase in the scope of work aimed at eliminating such complications [7], [8].

Accordingly, the attempt of producing companies to extend the life of wells almost always becomes one of the main tasks in the fields development and the prerogative when forming business plans [9].

\subsection{Literature review}

One of the main causes of behind-the-casing flows is poor-quality fastening of wells, in particular, the interval of productive horizons occurrence [10]. This is the result of the insufficient efficiency of technologies for their fastening 
used at this time (imperfection of technical means and grouting materials), which do not prevent the formation of channels in the cement stone, at its contact with the rock and casing string, as well as the destruction of the cement sheath from various loads [11].

Statistical analysis of the quality of oil and gas wells fastening over the past decade using standard grouting materials indicates the insufficient quality of the cement stone adhesion to the casing string (Table 1).

Table 1. Statistical analysis of the quality of oil and gas wells fastening at the geological enterprises of DP Poltavnaftohazheolohiia and SE Chernihiv Naftogaz Geologiya

\begin{tabular}{ccccc}
\hline \multirow{2}{*}{ Enterprise } & $\begin{array}{c}\text { Grouting } \\
\text { material }\end{array}$ & $\begin{array}{c}\text { The quality of the cement stone } \\
\text { contact with the casing string, } \\
\text { according to the well cementa- } \\
\text { tion acoustic control, \% }\end{array}$ \\
\cline { 2 - 5 } & $\begin{array}{c}\text { Fluid- } \\
\text { tight } \\
\text { contact }\end{array}$ & $\begin{array}{c}\text { Loose } \\
\text { contact }\end{array}$ & $\begin{array}{c}\text { Poor } \\
\text { contact }\end{array}$ \\
\hline \multirow{2}{*}{$\begin{array}{c}\text { DP Poltavnafto- } \\
\text { hazheolohiia }\end{array}$} & $\begin{array}{c}\text { Slag-sand } \\
\text { cement of } \\
\text { general } \\
\text { grinding } \\
\text { (ShPTsS-120) }\end{array}$ & 19.6 & 12.4 & 68.0 \\
\cline { 2 - 5 } & $\begin{array}{c}\text { Cement-ash } \\
\text { mixtures } \\
\text { (CZS) }\end{array}$ & 44.2 & 48.6 & 7.2 \\
\hline $\begin{array}{c}\text { SE Chernihiv } \\
\text { Naftogaz Geologiya }\end{array}$ & ShPTsS-120 & 20.1 & 13.7 & 66.2 \\
\cline { 2 - 5 } & CZS & 36.4 & 53.3 & 10.3 \\
\hline
\end{tabular}

The majority of gas, oil and water inflows occur in the first 2-8 hours of waiting for the cement hardening, which is largely due to a decrease in the hydrostatic pressure of the cement slurry column during the hardening process (more than $80 \%$ of the behind-the-casing gas, oil and water inflows) [12].

The emergence of behind-the-casing flows, according to most industry experts, is caused by loose contact of the cement sheath with the casing string and the rock. But in practice, such views are not always confirmed. In particular, in a majority of cases, despite the cementation acoustic control data, which correspond to a high degree of the cement stone adhesion to the casing string and the walls of the well, there are behind-the-casing and interstratal flows, which indicate a poor tightness of the cement sheath body [13].

The quality of well cementing, in which the migration of reservoir fluids is potentially possible, depends on a wide range of the grout slurry technological parameters. It also depends on the modes of the process itself: incomplete removal of flushing fluid and filter cake; incorrect choice of the grout slurry concentration; premature thickening; high filtration; high permeability in the early stages of cement hydration; significant volumetric shrinkage; osmotic masstransfer; destruction of the cement sheath due to its insufficient thermal and rust resistance; poor-quality contact of the cement stone with the casing string and well walls [14].

During the period of time when the cement stone is similar to a permeable matrix of hydration products, the pore space of which is filled with free water, the most favorable conditions are created for the reservoir fluid filtration through it. This may cause suffusion channelling.

In practice, the main condition for preventing fluid inflow during cementing operations is the correct selection of the grout slurry concentration when pumping it into the well. But, according to the literature data, the dynamics of a change in the pressure acting on the well walls during the cement stone structure formation at the early stages of its hydration is of no less importance. During the period when the grout slurry is a porous body, the potential danger of fluid breakthrough is maximum. This is conditioned by the fact that the cement sheath largely simulates an ideal soil, that is, a system of open capillaries, which are separated by thin walls of hydration products, and the active hydrostatic pressure on the fluid-saturated horizon is created only by the grouting fluid in the pores. As a result of the drawdown, filtration begins, first of the free grouting fluid, and then of the reservoir fluid. This phenomenon becomes the reason for the creation of stable suffusion channelling caused by the destruction of the skeleton, which has just begun to form [15].

In order to prevent behind-the-casing flows, it is proposed to achieve an optimal pressure distribution by cementing production strings with two portions of grout slurry with different time of hardening. In domestic practice, when cementing with the length of the casing lower section which overlaps the fluid-saturated horizons of more than 400 meters, it is supposed to differentiate the time of hardening the grout slurry portions along the column height so that the beginning of hardening of the lower portion is 2-3 hours less than that of the upper portion [16].

In the last 20 years, slag-sand cement of general grinding ShPTsS-120, oilwell portland cement PTsTI-100 for moderate and high temperatures, as well as cement-ash mixtures CZS have been used as the main grouting materials for cementing production strings in the geological exploration areas of Ukraine.

Mining-and-geological conditions are not always taken into account when choosing a formulation for cementing.

When using the Defecate additive, the PTsTI-100/D ratio is chosen arbitrarily [17], focusing only on the given concentration and the convenience of mixing the components, while the temperature at the well bottom is practically not taken into account. In many cases of using two portions of grout slurries for cementing the first sections of production strings in the temperature range of $1000-1500^{\circ} \mathrm{C}$, PTsTI- 100 is used as the first portion, which is unacceptable from the point of view of its limited thermal stability (up to $900^{\circ} \mathrm{C}$ ). The required gap in time is also not provided between the hardening periods of the first and second portions of grout slurries.

The reliability of productive horizons insulation is also not ensured by cementing with standard ShPTsS-120. This material does not have stable parameters in terms of various batches. In addition, grout slurries based on ShPTsS-120 are sedimentation unstable, and the stone formed is prone to shrinkage.

\subsection{Purpose and objectives of the research}

The purpose of the research is to substantiate the expediency of cement mix formulations of grout slurries with different content of a Defecate additive, which have a number of significant advantages over conventional slurries, their effective use when cementing reservoirs prone to absorption of cement slurry, as well as for preventing behind-the-casing flows and for cementing operations in the zone of abnormal pressures (hydraulic seam fracturing).

To achieve this purpose, the following objectives should be solved: determining the influence of the Defecate additive content on the cement mixture technological properties; study of a change in the grout slurry rheological characteristics at various temperature conditions; testing the formulation 
of grout slurries with different rates of strength development; substantiating the economic efficiency of using grout mixtures with the Defecate additive.

\section{Materials and methods for studying the properties}

The study of the cement mix formulations of grout slurries is performed using oilwell portland cement PTsTI-100 for moderate and high temperatures, plastic foam grains, nitrilotrimethylphosphonic acid and a Defecate.

Defecate is a sugar production waste formed during the defecation of sugar juice. The density of dry matter is $780-800 \mathrm{~kg} / \mathrm{m}^{3}$, residue on the sieve No. $0.03-5-8 \%$.

The chemical composition of the Defecate slightly varies depending on the type of raw material and production, but in a typical case, in a dried state at a moisture content of $25-30 \%$, it contains the elements represented in Table 2. Loss on calcination $-46-47 \%$, when converted to $\mathrm{CaCO}_{3}-82-90 \%$.

Table 2. Chemical composition of the Defecate additive

\begin{tabular}{lcccccc}
\hline $\begin{array}{l}\text { Name of a } \\
\text { substance }\end{array}$ & \multicolumn{5}{c}{ Chemical composition, mass fraction \% } \\
\cline { 2 - 7 } & $\begin{array}{c}\mathrm{Al}_{2} \mathrm{O}_{3} \\
+\mathrm{Fe}_{2} \mathrm{O}_{3}\end{array}$ & $\mathrm{CaO}$ & $\mathrm{MgO}$ & $\mathrm{SO}_{3}$ & $\begin{array}{c}\text { hydrate } \\
\text { oxide }\end{array}$ \\
\hline Defecate & $2.75-3.5$ & $1.8-2.5$ & $46-48$ & $1.0-1.2$ & $0.14-0.5$ & $4.5-5.5$ \\
\hline
\end{tabular}

The technical grout slurry parameters (mobility, concentration, water separation, pumpability, etc.) are studied in accordance with the requirements using the appropriate devices.

Plastic viscosity $\left(\eta_{p l}\right)$ and dynamic shear stress $\left(\tau_{0}\right)$ are determined using a rotary viscometer. When testing the cement slurries in production conditions, the pumpability assessing method is conducted using a consistometer of the KTS-3 type.

The cement slurry spreadability is determined using an instrument called an AzNII cone (KR according to TU 25-04-52-75). The cement slurry concentration is determined by special density hydrometers AG-1 or AG-2, which can be used to quickly and accurately determine the density in the field environment.

Using the Vicat apparatus, the time of setting is determined at temperatures up to $90^{\circ} \mathrm{C}$ at atmospheric pressure.

The dynamic viscosity of the calibration fluids is determined using an Ostwald capillary viscometer.

The rheological properties of grout slurries are studied on a rotary viscometer of the Reotest- 2 brand.

The cement stone is formed in autoclaves under conditions that simulate pressure and temperature at the well bottom (fluctuations in temperature parameters $\pm 5^{\circ} \mathrm{C}$, pressure $\pm 2 \mathrm{MPa}$ ). The strength value is measured on a hydraulic press.

\section{Research results}

The results of determined indicators characterizing the technological properties of cement slurries with a differentiated rate of strength development (concentration, fluidity, water separation) are shown in Table 3. As can be seen from the data in the table, by varying the ratio of PTsTI-100 components and the $\mathrm{W} / \mathrm{C}$ value, it is possible to obtain cement slurries with a concentration from 1310 to $1680 \mathrm{~kg} / \mathrm{m}^{3}$. If it is necessary to increase the concentration, it is recommended to introduce a weighting agent like barite [18].

Table 3. Technological properties of cement slurries containing the Defecate additive

\begin{tabular}{|c|c|c|c|c|c|c|}
\hline \multicolumn{2}{|c|}{ Mixture composition, \% } & \multirow{2}{*}{$\begin{array}{c}\text { Water-cement } \\
\text { ratio }(\mathrm{W} / \mathrm{C})\end{array}$} & \multirow{2}{*}{$\begin{array}{c}\text { Concentration, } \\
\mathrm{kg} / \mathrm{m}^{3}\end{array}$} & \multirow{2}{*}{$\begin{array}{c}\text { Fluidity, } \\
\text { m }\end{array}$} & \multirow{2}{*}{$\begin{array}{c}\text { Water } \\
\text { separation, } \mathrm{cm}^{3}\end{array}$} & \multirow{2}{*}{$\begin{array}{l}\text { Pumpability, } \\
\text { hours-minutes }\end{array}$} \\
\hline PTsTI-100 & Defecate & & & & & \\
\hline 100 & - & 0.50 & 1830 & 0.20 & 1.8 & $1-30$ \\
\hline 95 & 5 & 0.50 & 1780 & 0.22 & 1.8 & $1-50$ \\
\hline 90 & 10 & 0.60 & 1680 & 0.24 & 1.7 & $2-17$ \\
\hline 85 & 15 & 0.70 & 1550 & 0.25 & 1.8 & $2-35$ \\
\hline 80 & 20 & 0.80 & 1480 & 0.28 & 1.9 & $3-00$ \\
\hline
\end{tabular}

Based on these results, it is possible to state certain patterns associated with the change in the indicators of technological properties depending on the proportion of the Defecate additive included in the composition of the cement slurry. In particular, the fluidity of the cement slurry with the addition of $5 \%$ Defecate increases by $10 \%$ (Fig. 1a) in comparison with the cement slurry without it. With an increase in the Defecate proportion to $20 \%$, the fluidity increases by another $20 \%$. As for the pumpability, as evidenced by the data obtained (Fig. 1b), the presence of a Defecate in the cement slurry in the proportion of $20 \%$ doubles the pumpability from 1.5 to 3 hours.

A sufficiently high specific surface area ensures low water separation of the grout slurry. The optimum content of the Defecate additive is from 5 to $20 \%$. With a further increase in the Defecate content, the stone strength deteriorates, and with a decrease, the grout slurry concentration increases.

An important characteristic of the grout slurry is its rheological characteristics. They largely determine the hydraulic resistance value in the process of cementing the well, as well as influence on the completeness of the flushing fluid displacement from the casing string annulus. Table 4 summarizes the main results of plastic viscosity $(\eta)$ and dynamic shear stress $(\tau)$ measurements using a rotary viscometer.
Table 4. Rheological characteristics of grout slurries based on the Defecate additive

\begin{tabular}{|c|c|c|c|c|c|}
\hline \multicolumn{2}{|c|}{$\begin{array}{l}\text { Mixture composition, } \\
\text { mass fraction, } \%\end{array}$} & \multirow[t]{2}{*}{$\mathrm{W} / \mathrm{C}$} & \multirow[t]{2}{*}{$t,{ }^{\circ} \mathrm{C}$} & \multirow[t]{2}{*}{$\tau, \mathrm{Pa}$} & \multirow[t]{2}{*}{$\eta, \mathrm{Pa} \cdot \mathrm{s}$} \\
\hline PTsTI-100 & Defecate & & & & \\
\hline \multirow{2}{*}{100} & \multirow{2}{*}{0} & \multirow{2}{*}{0.50} & 20 & 16.9 & 0.110 \\
\hline & & & 75 & 30.1 & 0.153 \\
\hline \multirow{2}{*}{95} & \multirow{2}{*}{5} & \multirow{2}{*}{0.50} & 20 & 16.8 & 0.098 \\
\hline & & & 75 & 25.8 & 0.151 \\
\hline \multirow{2}{*}{90} & \multirow{2}{*}{10} & \multirow{2}{*}{0.55} & 20 & 16.4 & 0.082 \\
\hline & & & 75 & 22.1 & 0.090 \\
\hline \multirow{2}{*}{85} & \multirow{2}{*}{15} & \multirow{2}{*}{0.60} & 20 & 14.2 & 0.063 \\
\hline & & & 75 & 20.6 & 0.060 \\
\hline \multirow{2}{*}{80} & \multirow{2}{*}{20} & \multirow{2}{*}{0.65} & 20 & 12.1 & 0.058 \\
\hline & & & 75 & 15.4 & 0.043 \\
\hline
\end{tabular}

The presence of a Defecate in the mixture leads to a significant change in the dynamic shear stress, especially at elevated temperatures (Fig. 2a). Moreover, as the Defecate concentration increases, the dynamic shear stress is halved. This phenomenon can be explained by the blocking of active crystallization centers by Defecate fractions, slowing down of hydration processes and the construction of a coagulationcrystallization structure, which is especially characteristic at elevated temperatures. 
(a)

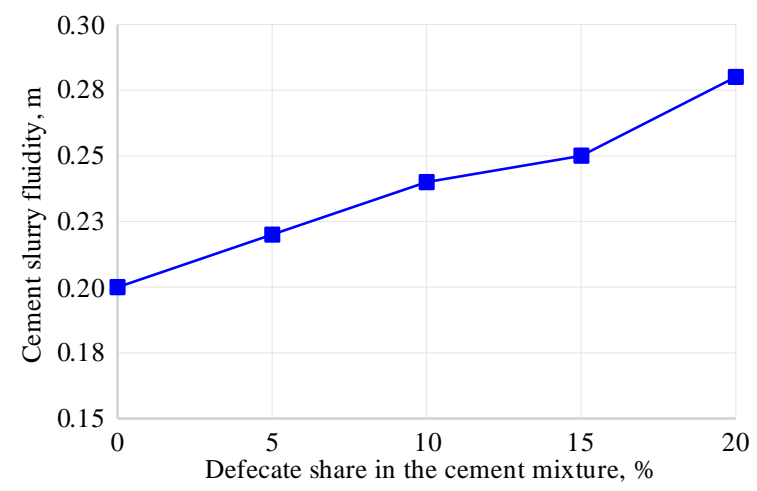

(b)

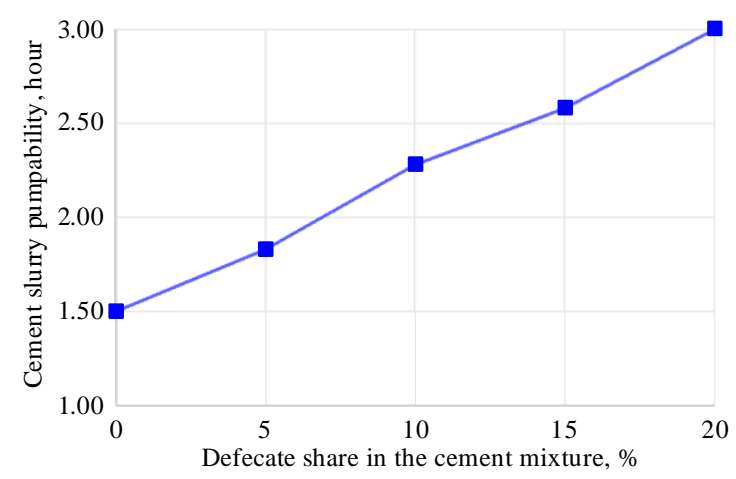

Figure 1. Dependency graph of the cement slurry technological properties on the Defecate additive content: (a) cement slurry fluidity; (b) cement slurry pumpability

(a)

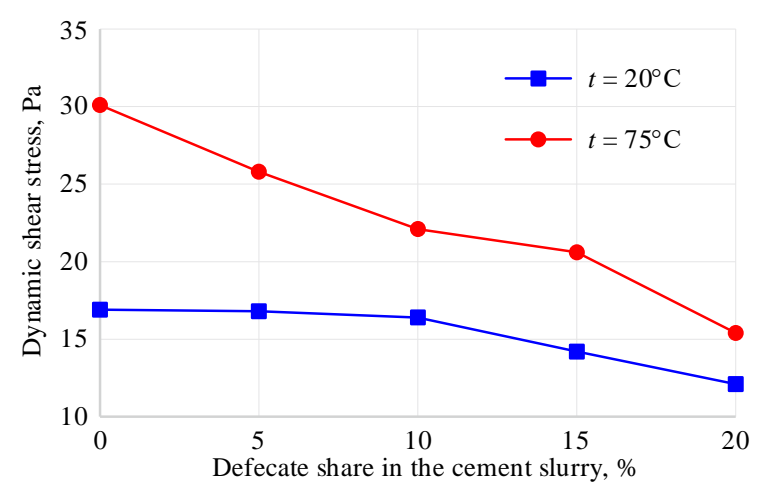

(b)

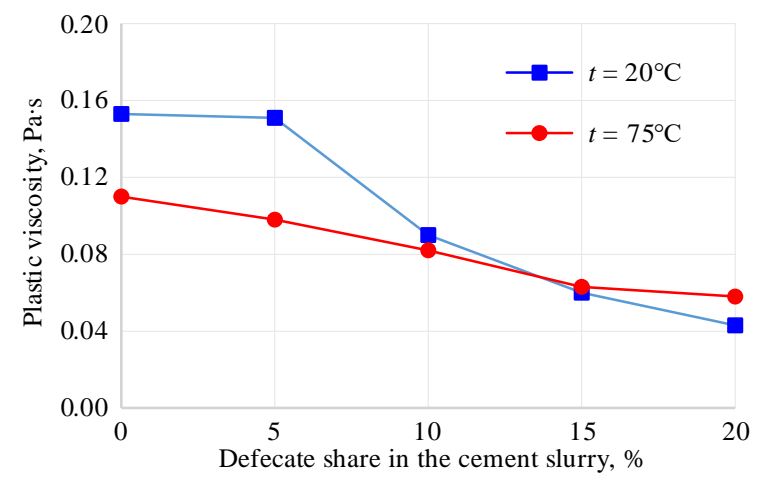

Figure 2. Dependency graph of the grout slurry rheological characteristics on the content of the Defecate additive: (a) dynamic shear stress; (b) plastic viscosity of the solution
The period of the grout slurry thickening is easily controlled using standard retarders such as nitrilotrimethylphosphonic acid. This makes possible to select the formulations with a differentiated rate of strength development.

The two formulation complexes are aimed to maintain the required pressure on fluid-saturated reservoirs while waiting for cement hardening. The formation of the coagulationcrystallization structure of the cement dispersion is accompanied by a decrease in pressure acting at the well bottom. Therefore, it is important to select the composite column of the grout slurry in such a way that its "upper part" is in a liquid state (before to start hardening) until the "lower part" acquires the required strength. This strength value, when the cement sheath body becomes impermeable to fluid, reaches about 1.5 MPa [19].

The "pairs" of formulations with the required parameters are selected according to the following scheme. At first, using a consistometer at temperatures of 75 and $100^{\circ} \mathrm{C}$ by leveling the ratios of the components in the Defecate and the proportion of added nitrilotrimethylphosphonic acid, several compositions have been selected with the pumpability time required for these conditions (3, 4 hours, respectively).

The grout slurries prepared according to the following criteria are stored in autoclaves for 6,7 and 8 hours at temperatures of 75 and $100^{\circ} \mathrm{C}$. The results of measuring the strength parameters of the cement stone based on the Defecate are shown in Table 5.

When drilling oil and gas wells, grout mixtures designed to delimit producing reservoirs prone to absorption and hydraulic fracturing should have a lightweight solution concentration. Based on the literature data, it is known that various substances, such as diatom earth, perlite, pozzolan, slags, ash and others, are used to reduce the grout slurry concentration [20].

The disadvantage of such grout mixtures is a relatively high lower concentration limit, poor pumpability, sedimentation instability, and low strength of the cement stone hardening.

It is known from the literature sources that the lightweight grouting materials, the closest in technical essence and the foreseeable result of the proposed grout mixture are those based on a mineral binder. Oilwell portland cement can be used as a mineral binder, and plastic foam grains with a fraction of $1.5-2.0 \mathrm{~mm}$ size can be used as a lightweight mineral additive with a ratio of components: plastic foam grains $2-3 \%$, and the rest is the oilwell portland cement.

Table 6 shows the technological properties of grout slurries based on Defecate.

When producing a lightweight grout slurry, the use of the Defecate mineral additive compared to the plastic foam grains makes possible to increase the grout slurry stability, improve pumpability, reduce the lower mark of the slurry concentration and increase the strength of the cement stone.

The economic efficiency from the grout mixtures introduction with partial replacement of cement for Defecate additive, calculated using the example of the No. 122 well of the Kulychykhynske NHKR, is presented in Table 7.

Thus, the obtained positive value of the economic effect confirms the expediency of introducing grout slurries using Defecate. 
Table 5. Formulations for grout slurries with different rates of strength development

\begin{tabular}{|c|c|c|c|c|c|c|c|c|c|}
\hline \multicolumn{2}{|c|}{ Mixture composition, $\%$} & \multirow{3}{*}{$\mathrm{W} / \mathrm{C}$} & \multirow{3}{*}{$\begin{array}{l}\text { Nitrilotrimethylphosphonic } \\
\text { acid additive, } \%\end{array}$} & \multicolumn{6}{|c|}{ Compression strength, MPa } \\
\hline \multirow{2}{*}{ PTsTI-100 } & \multirow{2}{*}{ Defecate } & & & \multicolumn{3}{|c|}{$t=75^{\circ} \mathrm{C}, P=0.1 \mathrm{MPa}$} & \multicolumn{3}{|c|}{$t=100^{\circ} \mathrm{C}, P=30 \mathrm{MPa}$} \\
\hline & & & & 6 hours & 7 hours & 8 hours & 6 hours & 7 hours & 8 hours \\
\hline 100 & - & 0.50 & 0.03 & 1.9 & - & - & - & - & - \\
\hline 95 & 5 & 0.50 & 0.02 & 1.5 & - & - & - & - & - \\
\hline 90 & 10 & 0.55 & 0.015 & 0.1 & 0.2 & 1.5 & - & - & - \\
\hline 80 & 20 & 0.55 & 0.01 & 0.4 & 1.6 & - & - & - & - \\
\hline 95 & 5 & 0.55 & 0.06 & - & - & - & 0.6 & 2.2 & - \\
\hline 90 & 10 & 0.50 & 0.10 & - & - & - & 0.2 & 1.8 & - \\
\hline 80 & 20 & 0.50 & 0.12 & - & - & - & 0.0 & 0.6 & 1.5 \\
\hline
\end{tabular}

Table 6. Technological properties of grout slurries and cement stone with the use of Defecate

\begin{tabular}{|c|c|c|c|c|c|c|c|c|}
\hline \multicolumn{3}{|c|}{ Mixture composition } & \multirow{3}{*}{$\mathrm{W} / \mathrm{C}$} & \multirow{3}{*}{$\begin{array}{l}\text { Fluidity, } \\
\text { m }\end{array}$} & \multirow{3}{*}{$\begin{array}{l}\text { Concentration, } \\
\mathrm{kg} / \mathrm{m}^{3}\end{array}$} & \multirow{3}{*}{$\begin{array}{c}\text { Water } \\
\text { separation, } \mathrm{cm}^{3}\end{array}$} & \multirow{2}{*}{\multicolumn{2}{|c|}{$\begin{array}{c}\text { Compression strength, } \mathrm{MPa} \\
2 \text { days }\end{array}$}} \\
\hline PTsTI-100, & Plastic foam & Defecate $\%$ & & & & & & \\
\hline & grains, $\%$ & Dereate, & & & & & $22^{\circ} \mathrm{C}$ & $75^{\circ} \mathrm{C}$ \\
\hline 98 & 2.0 & - & 0.50 & 0.19 & 1650 & 2.2 & 0.5 & 1.1 \\
\hline 97 & 3.0 & - & 0.55 & 0.2 & 1610 & 2.0 & 0.4 & 0.9 \\
\hline 96 & - & 4 & 0.50 & 0.22 & 1680 & 1.8 & 1.2 & 1.8 \\
\hline 93 & - & 7 & 0.62 & 0.23 & 1520 & 1.9 & 1.0 & 1.8 \\
\hline 90 & - & 10 & 0.55 & 0.22 & 1510 & 1.7 & 1.4 & 2.0 \\
\hline 88 & - & 12 & 0.67 & 0.22 & 1420 & 2.0 & 1.3 & 1.9 \\
\hline 86 & - & 14 & 0.70 & 0.25 & 1370 & 2.1 & 1.0 & 1.7 \\
\hline 84 & - & 16 & 0.75 & 0.25 & 1310 & 2,0 & 0.9 & 2.0 \\
\hline 82 & - & 18 & 0.65 & 0.22 & 1400 & 1.8 & 1.5 & 2.4 \\
\hline 80 & - & 20 & 0.65 & 0.24 & 1380 & 1.7 & 0.9 & 2.2 \\
\hline
\end{tabular}

Table 7. Technical-and-economic indicators of the grout mixtures introduction with the replacement of $20 \%$ of cement with the Defecate additive using the example of the No. 122 well of the Kulychykhynske NHKR

\begin{tabular}{|c|c|c|c|c|c|c|c|}
\hline No. & \multicolumn{2}{|r|}{ Indicator name } & $\begin{array}{c}\text { Unit of } \\
\text { measurement }\end{array}$ & Designation & $\begin{array}{c}\text { Before } \\
\text { introduction }\end{array}$ & $\begin{array}{c}\text { After } \\
\text { introduction }\end{array}$ & Deviation \\
\hline 1 & \multicolumn{2}{|c|}{ Depth of repair work } & $\mathrm{m}$ & $H$ & 4140 & 4140 & $x$ \\
\hline 2 & \multicolumn{2}{|c|}{ Cement slurry volume } & $\mathrm{m}^{3}$ & $Q$ & 172 & 172 & - \\
\hline 3 & \multicolumn{2}{|c|}{$\begin{array}{l}\text { Yield of solution from } 1 \text { ton of grout } \\
\text { mixture (according to formulation) }\end{array}$} & $\mathrm{m}^{3}$ & $q$ & 0.84 & 0.78 & -0.06 \\
\hline 4 & \multicolumn{2}{|c|}{ Consumption of grouting materials } & $\mathrm{m} / \mathrm{m}^{3}$ & $A=Q / q$ & 204.8 & 220.5 & +15.17 \\
\hline 5 & \multicolumn{2}{|c|}{ Ratio of PTsTI-100/D } & $\%$ & & 100 & $80 / 20$ & $x$ \\
\hline 6 & \multicolumn{2}{|c|}{$\begin{array}{l}\text { Cost of } 1 \text { ton of cement (including } \\
\text { transportation costs) }\end{array}$} & $\mathrm{UAH} /$ ton & $C_{1}$ & 6490 & 6490 & - \\
\hline 7 & \multicolumn{2}{|c|}{$\begin{array}{l}\text { Cost of } 1 \text { ton of cement slurry } \\
\text { (including transportation costs) }\end{array}$} & $\mathrm{UAH} /$ ton & $C_{2}$ & 6490 & 5522 & -968 \\
\hline 8 & \multicolumn{2}{|c|}{$\begin{array}{l}\text { Specific consumption of grout } \\
\text { mixture per } 1 \mathrm{~m} \text { of well fastening }\end{array}$} & $\mathrm{m} / \mathrm{m}^{3}$ & $F=A / H$ & 0.049 & 0.053 & +0.004 \\
\hline 9 & \multicolumn{2}{|c|}{$\begin{array}{l}\text { Specific costs for grouting materials } \\
\text { per } 1 \mathrm{~m} \text { of well fastening } \\
\text { Total economic effect }\end{array}$} & $\mathrm{UAH} / \mathrm{m}$ & $I=C_{1} \cdot F$ & 321.05 & 294.11 & -26.94 \\
\hline 10 & $E=$ & {$\left[C_{2} \cdot \frac{F_{1}}{F_{2}}+\frac{I_{1}-I_{2}}{F_{2}}-C_{2}\right] \cdot A_{2}$} & thousand UAH & & $x$ & 4321.54 & $x$ \\
\hline
\end{tabular}

\section{Conclusions}

Grout mixtures must correspond to the specific miningand-geological conditions of a particular well and have high thermal stability. These requirements are met by mixtures based on PTsTI-100 oilwell portland cement and Defecate mineral additive. These mixtures have a number of significant advantages, such as high sedimentation stability, the ability to control the solution concentration within a wide range, high strength of the cement stone, low rheological parameters of the solution in comparison with the conventional ones used for cementing the wells. A positive aspect is that the substances based on PTsTI-100/D can be used for cementing the reservoirs prone to absorption of the cement slurry, as well as for cementing operations in the zone of abnormal pressures.
The above properties have been studied with the purpose to create two mixture formulations when cementing the strings with two portions of cement slurry with different time of hardening. The two formulation complexes are aimed to maintain the required pressure on fluid-saturated reservoirs while waiting for cement hardening. The formation of the coagulation-crystallization structure of the cement dispersion is accompanied by a decrease in pressure acting at the well bottom. Therefore, it is important to select the composite column of the grout slurry in such a way that its "upper part" is in a liquid state (before to start hardening) until the "lower part" acquires the required strength. This strength value, when the cement sheath body becomes impermeable to fluid, reaches about 1.5 MPa. The use of PTsTI-100/D grout mixture will expand the raw material base for obtaining lightweight grout mixtures. 
The properties of such a solution make it possible to use a grout mixture for cementing the wells in the zone of abnormal pressures. The use of mixtures based on PTsTI100/D satisfies not only the technological requirements of cementing operations, but also makes the process of delimitation of reservoirs much cheaper. For cementing the wells with high bottomhole pressures, it is possible to use solutions based on PTsTI-100/D with the addition of a weighting agent such as barite.

The No. 122 well was put into operation at the Kulychykhynske NHKR (oil and gas condensate field) on April 1, 2013. For 2 years of operation, the well was heavily flooded and required a major repair. The work to isolate the inflow of water was carried out at the well, but the desired result has not been achieved.

Therefore, having analysed the state of the well and the ways of water inflow into the well, it is proposed to isolate the aquifer with a grout slurry, which is prepared on the basis of PTsTI-100 and the Defecate mineral additive in the ratio PTsTI-100/D - 80/20, weighted with barite and with the determination of the cement plug in the range of $4117.8-4140 \mathrm{~m}$.

\section{Acknowledgements}

This research would have been impossible without the support of V.O. Onyshchenko, Doctor of Economics, Professor, Rector of the National University "Yuri Kondratyuk Poltava Polytechnic" and the opportunity to conduct the research in the laboratory of drilling fluids, which is located on the territory of the university. The authors are grateful to M.O. Bidnosheia, Candidate of Technical Sciences, for scientific advice and knowledge sharing.

\section{References}

[1] Orlovskyi, V.M., \& Pokhylko, A.M. (2017). Modified lightweight plugging material. Mineral Resources of Ukraine, (3), 40-43.

[2] Horskyi, V.F. (2006). Grouting materials and mixtures. Chernivtsi, Ukraine: Print, $524 \mathrm{p}$.

[3] Danyushevskiy, V.S., Aliev, R.M., \& Tolstyh, I.F. (1987). Reference guide back-fill materials. Moskva, Russia: Nedra, $373 \mathrm{p}$.
[4] Bulatov, A.I., \& Danyushevskiy, V.S. (1987). Grouting materials (p. 164-167). Moskva, Russia: Nedra.

[5] Novohatskiy, D.F. (1972). Special oil-well cements. Burenie, (6), 26-28.

[6] Gafarov, Sh.A., Shamaev, G.A., \& Safonov, E.H. (2005). Features of the filtration of non - Newtonian oils in carbonate porous media. Oil Industry, (11), 52-54.

[7] Rubel, V.P., \& Petruniak, M.V. (2018). Evaluation of the effectiveness of intensification methods on the example of the conditions of the Bilskoye oil and gas condensate field. World Science, 6(34), 46-51.

[8] Rubel, V.P., Petruniak, M.V., \& Liashenko, A.V. (2018). Improving the efficiency of gas production intensification technology as exemplified by the Kolomatsk gas condensate field. International Trends in Science and Technology, (1), 57-60.

[9] Vynnykov, Y., Manhura, A., Zimin, O., \& Matviienko, A. (2019). Use of thermal and magnetic devices for prevention of asphaltene, resin, and wax deposits on oil equipment surfaces. Mining of Mineral Deposits, 13(2), 34-40. https://doi.org/10.33271/mining13.02.034

[10] Antipin, Yu.V., Lysenkov, A.B., Karpov, A.A., Tukhteev, P.M., Ibraev, P.A., \& Stenechkin, Yu.N. (2007). Intensification of oil production from carbonate formations. Ufa Oil Industry, (7).

[11] Gallyamov, I.M., Vakhitov, T.M., Shafikova, E.A., Apkarimova, G.I., Sudakov, M.S., \& Samigullin, I.F. (2008). To the problem of applicability of polymer compositions at low temperatures. New in Geology and Development of Oil Fields of Bashkortostan, (120), 221-225.

[12] Novohatskiy, D.F. (1972). Special oil-well cements. Burenie, (6), $26-28$.

[13] Novohatskiy, D.F., \& Voloshin, V.A. (1978). Ways of improving the quality and prospects of production of cement materials to secure oil and gas wells. Burenie, (11), 19-22.

[14] TU U729755.01-94. (1994). Portland cement of componentpalette for normal and moderate temperatures, $13 \mathrm{p}$.

[15] Orlovskyi, V.M., Mykhailenko, S.H., \& Luzhanytsia, O.V. (2010). New facilitated and easy grouting materials. Naukovyi Visnyk IvanoFrankivskoho Natsionalnoho Universytetu Nafty i Hazu, (3), 10-14.

[16] Luzhanytsia, O.V., Mykhailenko, S.H., Orlovskyi, V.M., \& Martynov, D.V. (2006). Tamponade mix. Patent No. 13254, Ukraine.

[17] Chatterjee, S., \& Hadi, A.S. (2006). Regression analysis by example. Wiley Series in Probability and Statistics. Hoboken, New Jersey: John Wiley \& Sons, 385 p. https://doi.org/10.1002/0470055464

[18] Patsy, E. (2018). Advances in unconventional gas. Solutions to Meet Growing Gas Demand Worldwide. Retrieved from: www.hartenergy.com

[19] Campbell, B.L., \& Chmilowski, W. (1975). Effective stimulation of low-permeability gas wells in Western Canada. Journal of Canadian Petroleum Technology, 14(02), 17-22. https://doi.org/10.2118/75-02-01

[20] Ko, S.C.M., Stanton, P.M., \& Stephenson, D.J. (1985). Tertiary recovery potential of $\mathrm{CO}_{2}$ flooding in Joffre Viking Pool, Alberta. Journal of Canadian Petroleum Technology, 24(01), 36-43. https://doi.org/10.2118/85-01-01

\section{Використання тампонажних розчинів із вмістом добавки “Дефекат" для ефективного цементування свердловин}

\section{М. Петруняк, В. Рубель, В. Чевганова, С. Кулакова}

Мета. Дослідження та обгрунтування доцільності рецептур цементних сумішей тампонажних розчинів із різним вмістом добавки “Дефекат" та їх ефективності використання при цементуванні пластів, схильних до поглинання цементного розчину, для попередження міжколонних перетоків, а також для проведення цементувальних робіт у зоні аномальних тисків (гідророзрив пласта).

Методика. Використовувались аналітичні та експериментальні дослідження фізико-хімічних властивостей тампонажних розчинів, а саме: визначення впливу вмісту добавки “Дефекат” на технологічні властивості цементної суміші; встановлення зміни реологічних характеристик тампонажних розчинів при різних температурних режимах; дослідження рецептури тампонажних розчинів 3 різним темпом набору міцності; доведення економічної ефективності використання тампонажних сумішей з добавкою “Дефекат”.

Результати. Встановлено, що рухливість цементної суміші при додаванні дефекату в кількості 5-20\% 3більшується на 10-20\%, при подальшому збільшенні вмісту дефекату міцність каменю погіршується, при зменшенні - збільшується густина тампонажного розчину. Встановлено, що наявність дефекату в цементній суміші у кількості $20 \%$ збільшує прокачуваність цементного розчину вдвічі: з 1.5 до 3-х годин. Доведено економічну ефективність використання даних сумішей при проведенні ізоляційних робіт на прикладі свердловини №122 Куличихінського НГКР. Удосконалено рецептури тампонажних розчинів 3 добавкою “Дефекат”, які рекомендовано застосовувати для проведення ремонтно-ізоляційних робіт для розмежування продуктивних пластів, схильних до поглинання, міжколонних перетоків та гідророзривів.

Наукова новизна. Встановлено нові залежності технологічних та реологічних характеристик тампонажних розчинів від вмісту добавки “Дефекат”, що дозволяє визначити їі оптимальну кількість.

Практична значимість. Застосування тампонажної суміші на основі “Дефекат” дозволить розширити сировинну базу для одержання полегшених тампонажних розчинів. Властивості такого розчину дозволяють застосовувати тампонажну суміш для цементування свердловин у зоні аномальних тисків й робить процес розмежування пластів значно дешевшим.

Ключові слова: свердловина, міжколонні перетоки, продуктивний пласт, талпонажний розчин, дефекат 


\section{Использование тампонажных растворов с содержанием добавки “Дефекат” для эффективного цементирования скважин}

\section{М. Петруняк, В. Рубель, В. Чевганова, С. Кулакова}

Цель. Исследование и обоснование целесообразности рецептур цементных смесей тампонажных растворов с различным содержанием добавки“Дефекат” и их эффективности использования при цементировании пластов, склонных к поглощению цементного раствора, для предупреждения межколонных перетоков, а также для проведения цементировочных работ в зоне аномальных давлений (гидроразрыв пласта).

Методика. Использовались аналитические и экспериментальные исследования физико-химических свойств тампонажных растворов, а именно: определение влияния содержания добавки“Дефекат” на технологические свойства цементной смеси; установление изменений реологических характеристик тампонажных растворов при различных температурных режимах; исследования рецептуры тампонажных растворов с различным темпом набора прочности; доказание экономической эффективность использования тампонажных смесей с добавкой“Дефекат”.

Результаты. Установлено, что подвижность цементной смеси при добавлении дефеката в количестве 5-20\% увеличивается на $10-20 \%$, при дальнейшем увеличении содержания дефеката прочность камня ухудшается, при уменьшении - увеличивается плотность тампонажного раствора. Установлено, что наличие дефеката в цементной смеси в количестве $20 \%$ увеличивает прокачиваемость цементного раствора вдвое: с 1.5 до 3-х часов. Доказана экономическая эффективность использования данных смесей при проведении изоляционных работ на примере скважины №122 Куличихинского НГКМ. Усовершенствованы рецептуры тампонажных растворов с добавкой “Дефекат”, которые рекомендуется применять для проведения ремонтно-изоляционных работ для разграничения продуктивных пластов, склонных к поглощению, межколонных перетоков и гидроразрывов.

Научная новизна. Установлены новые зависимости технологических и реологических характеристик тампонажных растворов от содержания добавки “Дефекат”, что позволяет определить ее оптимальное количество.

Практическая значимость. Применение тампонажной смеси на основе “Дефекат” позволит расширить сырьевую базу для получения облегченных тампонажных растворов. Свойства такого раствора позволяют применять тампонажную смесь для цементирования скважин в зоне аномальных давлений и делает процесс разграничения пластов значительно дешевле.

Ключевые слова: скважина, межколонные перетоки, продуктивный пласт, тампонажный раствор, дефекат 